\title{
SPATIAL DYNAMICS OF SEMIDECIDUOUS SEASONAL FORESTS: CASE STUDY IN THE TURVO SUJO RIVER BASIN IN SOUTHEASTERN BRAZIL, BETWEEN THE YEARS OF 2003 AND $2016^{1}$
}

Isa Rafaela Alves ${ }^{2 *}$, Cibele Hummel do Amaral ${ }^{3}$, José Marinaldo Gleriani ${ }^{3}$ and Isadora Fausto Queiroz $\mathrm{Cabral}^{2}$

\footnotetext{
${ }^{1}$ Received on 25.04.2018 accepted for publication on 30.08.2018.

${ }^{2}$ Universidade Federal de Viçosa, Graduada em Engenharia Florestal, Viçosa, MG-Brasil. E-mail: <isa.rafalves@gmail.com> and $<$ isadorafqcabral@gmail.com>.

${ }^{3}$ Universidade Federal de Viçosa, Departamento de Engenharia Florestal, Viçosa, MG-Brasil. E-mail: <cibeleha@gmail.com> and $<$ gleriani@ufv.br>.

*Corresponding author.
}

ABSTRACT - The Agência Nacional das Águas (ANA) states that Brazil faces a water shortage problem since 2012 , and it is linked with the conservation of the country's watersheds directly. It is possible to track the landscape changes and its conservation state through satellite images. This study aims to analyze the spatial dynamics of Semideciduous Seasonal Forest (FES) fragments in the basin of the river Turvo Sujo, in Minas Gerais, southeastern Brazil, between the years of 2013 and 2016, and how this dynamic relates to the terrain aspect. In order to accomplish that, we used images of the Landsat series with geometric, radiometric and atmospheric corrections. For processing those images, samples of five categories of land cover and use were collected from RGB compositions. Maximum Likelihood was used to classify the images, and the overall accuracy, the confusion matrix, and the User's and Producer's accuracies per category were later obtained during the validation process. In 2003 the SSE occupied an area of 6.956 hectares, with highly fragmented disposition. Between 2003 and 2016 the native forest increased 42\% (about 3.053 hectares of regrowth within 13 years), resulting in a total of 10.009 hectares in 2016. The fragments of Semideciduous Seasonal Forest are more frequently present in the South, Southeast, Southwest and West aspects in both years, 2003 and 2016. However, the forest regrowth a long those years did not follow that evidence, with the regrowth occurring equally in all the exposition faces, except in the plain terrains, that represents only $0,03 \%$ of the studied watershed. That is an evidence relevant and positive, which must be monitored, once it is necessary to conserve all terrain aspects for water availability and quality maintenance within watersheds.

Keywords: Forest regrowth; Terrain aspect; Remote sensing.

\section{DINAMMICA ESPACIAL DE FLORESTAS ESTACIONAIS SEMIDECIDUAIS: CASO DE ESTUDO NA BACIA DO RIO TURVO SUJO NO SUDESTE DO BRASIL, ENTRE OS ANOS DE 2003 E 2016}

\begin{abstract}
RESUMO - De acordo com a Agência Nacional das Águas (ANA), a escassez de água vem sendo um problema brasileiro desde 2012 e está diretamente relacionado com a conservação das bacias hidrográficas. É possível monitorar as mudanças da paisagem e conservação dessas bacias com imagens provenientes de sensores orbitais. O trabalho teve como objetivo analisar a dinâmica espacial de fragmentos de Florestas Estacionais Semideciduais (FES) na bacia do Rio Turvo Sujo, em Minas Gerais, no sudeste do Brasil, entre os anos de 2003 e 2016, bem como analisar sua relação com o relevo. Foram utilizadas imagens da série Landsat com correções geométrica, radiométrica e atmosférica. Para o processamento, amostras de cinco classes de uso e cobertura da terra foram coletadas a partir de composições $R G B$ das imagens. As imagens foram classificadas por Máxima Verossimilhança e as exatidões globais, matriz de confusão e erros de comissão e omissão por classe foram obtidas na validação. Em 2003 a FES ocupava uma área de 6.956 hectares, com fragmentações acentuadas. Entre 2003 e 2016 as áreas de FES tiveram um aumento de 42\% (3.053 hectares de regeneração), cobrindo 10.009 hectares da bacia em estudo em 2016. Os fragmentos de FES apresentaram maior concentração nas faces Sul, Sudeste, Sudoeste e Oeste em ambos os anos de estudo. Contudo a regeneração florestal entre
\end{abstract}


esses anos não seguiu o mesmo padrão, ocupando semelhantemente todas as faces de exposição com exceção dos terrenos planos, que ocupam apenas 0,03\% da bacia em questão. Este é um aspecto relevante e positivo, que deve ser monitorado, tendo em vista a necessidade de conservação de todas as faces do relevo para manutenção da disponibilidade e qualidade dos recursos hídricos nas bacias hidrográficas.

Palavras-Chave: Regeneração florestal; aspecto de exposição do terreno; sensoriamento remoto

\section{INTRODUCTION}

The Atlantic Forest has been extensively studied due to the large biodiversity of the physiognomic-ecologic systems that constitutes it, among them the Dense Ombrophilous, Mixed Ombrophilous, Open Ombrophilous, Semideciduous and Deciduous Forests (IBGE 2012). According to the Brazilian Ministry of Environment, the Atlantic Forest domain originally occupied 1.300.000 $\mathrm{Km}^{2}$, across seventeen Brazilian states. Nowadays, around $67 \%$ of the Brazilian population lives in these areas, leading to the huge fragmentation of the forests (Brasil, 2017). At present, those forests occupy $12,5 \%$ of its original territory, with most of the fragments filling less than 50 ha and being farther than $100 \mathrm{~m}$ from the edges of each other, which reduces the chances of the biodiversity to support itself (Ribeiro et al., 2009; Fundação SOS, 2017a).

The state of Minas Gerais headed the deforestation ranking of the SOS Mata Atlântica foundation for seven of the past nine editions of the "Atlas dos Remanescentes Florestais". However, the placement is mostly resulting from the deforestation in three municipalities in the northern region of the state, with strong forestry activities connected to charcoal industries (Fundação SOS, 2017b). Among the municipalities of the Turvo Sujo River basin, in the southeastern Minas Gerais, Viçosa and Teixeiras presented zero ha of deforestation since 2010. Coimbra presented 6,33 ha of deforestation in 2010 , but after that year the rate also fell to zero. However, the report does not introduce forest dynamics values to the city of Cajuri (Fundação SOS, 2017b).

The forest fragmentation and the environmental degradation, combined to the increasing of rainfall index anomalies in southeastern Brazil (Diniz et al., 2018), have been a growing concern to the country due to the unbalance between the availability and demand for hydric resources (ANA, 2015). According to Coelho et al. (2015), a period of decrease in the rainfall index on summer months (December to February), for instance, has been observed in southeastern Brazil for over a decade, since 1998. In Viçosa, Minas Gerais, for example, the annual

Revista Árvore. 2018;42(5):e420507 rainfall does not reach the annual average of $1.326 \mathrm{~mm}$ since 2015 (Caram, 2007; INMET, 2018).

The watershed conservation, as well as the rainfall recurrence, has a major role in the community life as they ensure their water supply (Cristofoletti, 1981). The rainfall reaches the water courses through these basins, so their conservation status is directly linked to the quality and amount of the water resources. That is the reason to consider the importance of the watershed as a dynamic exchange system and a component of territorial planning in which exchanges of ecological and hydrological units occur (Silva et al., 2006; Carvalho et al., 2010).

For this reason, the spatial-temporal tracking of the watersheds' status to base actions for preserving or recovering them is indispensable nowadays, in order to provide a proper water supply to the population. Some experts point out that besides the knowledge of species settlement, other factors are fundamental to the success of a forest natural regrowth as: seed dispersal, topography, edaphic factors and the disturbances that may naturally happen (Chazdon, 2003; Ceccon et al., 2006; Bader et al., 2007). In this regard, the terrain aspects are essential to understand the forest occupancy dynamic, being the south orientated slopes being known to the countryside population as the "noruega" or "cold lands", and the north oriented as "soalheira" or "warm lands". The slopes with a northern aspect receive the first and last sunrays of the day, whereas the southern aspect presents dew deposition for a longer amount of time, resulting from a longer period of shading (Oliveira, 1995). In the slopes with southern (southeastern, southwestern) aspect the microclimate is favorable to regrowth, receiving more humidity and lower direct sunlight (Santos et al., 2017).

The inaccessibility of some places to gather information, besides the need to observe the forests dynamics at different temporal and spatial scales, makes the remote sensing a suitable option to collect data (Basnet, 1992). The capability of satellite-based sensor technologies to cover large amounts of land and obtain data at different temporal scales allows the monitoring of the forests' development (Kayiranga et al. 2016).

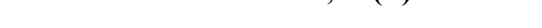


Besides, topographic surveying is crucial to understand the forest dynamics, which relates with the landforms, slope, orientation and terrain aspect (Rosa et al., 2017). These data can be easily obtained from Digital Elevation Models, which are also remote sensing products.

This paper intends to analyze the spatial dynamic of the Semideciduous Seasonal Forest (SSF) in the Turvo Sujo River basin in Minas Gerais State, southeastern Brazil, between the years 2003 and 2016, and how it relates with the terrain aspect. In particular, this study seeks to analyze if there was a decrease (deforestation) or increase (forest regrowth) of native forest in the watershed between those years, and if there is a pattern of spatial arrangement of the SSF remaining fragments, the deforestation and the natural regrowth events in relation to the terrain aspects.

\section{MATERIALAND METHODS}

\subsection{Material}

\subsubsection{Study area}

The Turvo Sujo River basin has 40.386 ha and is located in the Zona da Mata Mineira, in the cities of Coimbra, Cajuri, Teixeiras and Viçosa, in Minas Gerais State, southeastern Brazil. The climate is defined as CWA by the Köppen-Geiger classification, subtropical, marked by dry winters and wet summers. The studied area is located in the domain of Semideciduous Seasonal Forest (SSF) that, in tropical areas, presents itself in areas that face a winter drought and intense summer rainfall (Cabral, 2016). The Turvo Sujo River mouth is at the river Turvo Limpo, and it belongs to the Doce River basin. (Figure 1).

\subsubsection{Remote sensing data}

This study analyzed an image from the Thematic Mapper (Landsat 5) sensor, with 6 bands, from July 6,2003 , and an image from the Operational Land Imager (Landsat 8) sensor, with 9 bands, from August 10, 2016, both on path 217, row 74, in WGS84 datum, with geometric resolution of $30 \mathrm{~m}$. Those images are provided free of charge by the United States Geological Survey (USGS, 2017), with the geometric, radiometric and atmospheric corrections already made.

Also provided by the United States Geological Survey (USGS, 2017), a Digital Elevation Model from Shuttle Radar Topography Mission (SRTM) 1 ArcSecond Global, with spatial resolution of 30 meters was used.

\subsection{MEtHOds}

\subsubsection{Supervised classification}

In order to develop the research, the studied zones were divided in five classes: Native Forest, Silviculture/

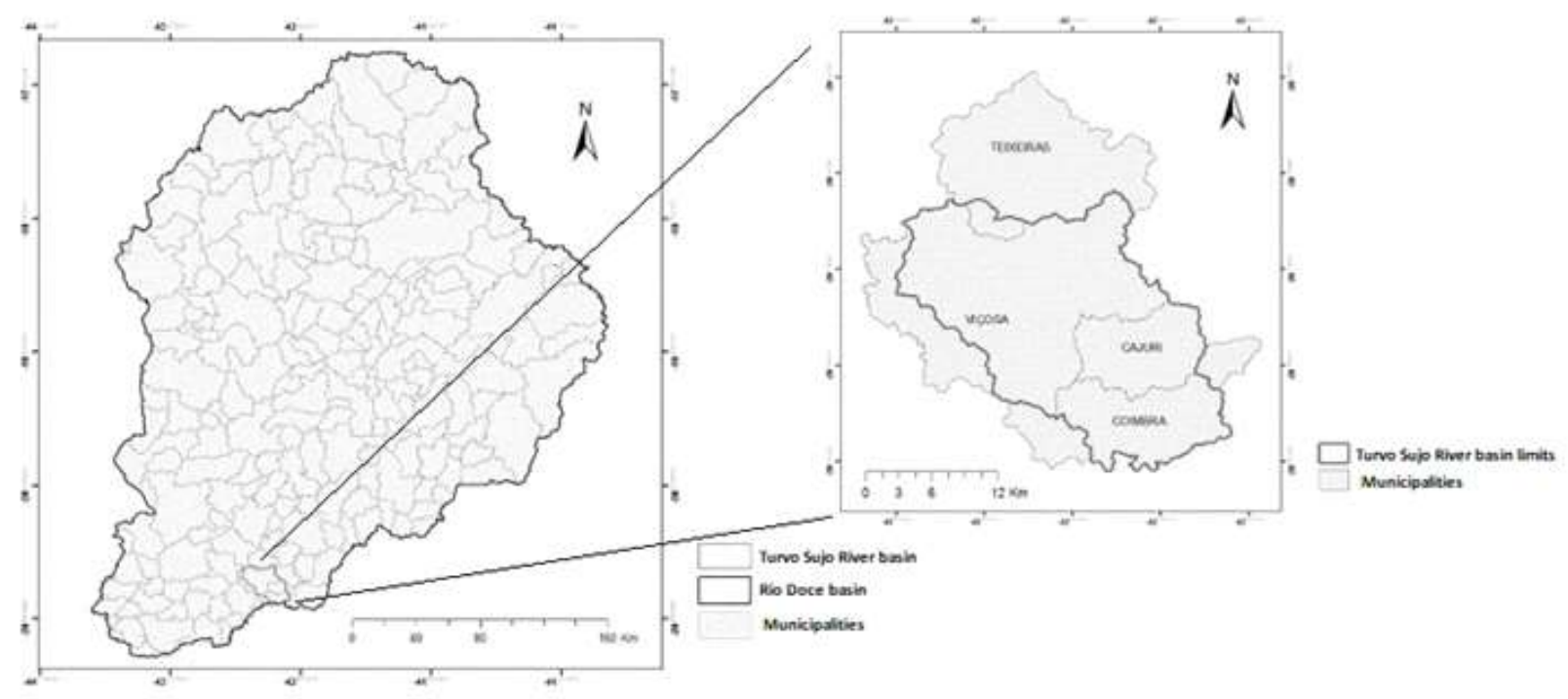

Figure 1 - Turvo Sujo river basin, located in Minas Gerais and belonging to Rio Doce basin.

Figura 1 - Localização da Sub-bacia do Rio Turvo Sujo, localizada em Minas Gerais e pertencente à Bacia hidrográfica do Rio Doce. 
Agriculture, Pasture, Exposed Soil and Water. For training, a total amount of 900 pixels were accounted for each class, except Water, that had 160 pixels due to the lack of samples in the scene.

The supervised classification was performed with the software ENVI 5.3 (Exelis - Boulder, United States), by the tool Maximum Likelihood Classification. This algorithm is based on the probability of a pixel to belong to a certain class, with the statistical distance being established with a covariance matrix, considering the location, shape and size of the pixels (Shiba et al., 2005).

\subsubsection{Validation}

The validation of the classification was made through the tool Confusion Matrix Using Ground Truth ROIs in ENVI. The samples, both training and validation ones, were collected from RGB compositions of the images acquired for the research and from sample points collected in the field, in certain sections of the basin, with navigational GPS GARMIN/GPSMAP 64s (Garmin Ltda. - Schaffhausen, Switzerland). A total amount of 630 pixels per class were sampled, with the exception of the Water class, that had 160 pixels.

The classification provided the confusion matrix, the kappa coefficient, the overall accuracy and the user's and producer's accuracies per class. The user's errors correspond to the pixels inserted in a class to which they do not belong, while the producer's errors refer to the pixels that are not in their proper class (Ferreira et al., 2007).

\subsubsection{Data set analysis}

After the classification of the different land covers obtained from the images Landsat TM from 2003 and OLI from 2016, the areas classified as Native Forest, in both years, were converted into polygons and cut with the tool Clip, at the software ArcGis 10.3. (Esri, Redlands, CA, United States).

The tool Erase was used to obtain the difference between the areas of native forest of the two years, referring to the natural regrowth and the deforestation. In order to generate the polygons of remaining forests throughout the studied years, the tool Intersect was used. In the same software, random points were distributed, with a minimum distance restriction of 30 meters in the shapefiles from 2003, 2016, regrowth and deforestation, considering the spatial resolution of the classified images and the products.
The tool Aspect was used on the Digital Elevation Model, every 30 meters, to obtain the terrain aspect of the landscape. With the tool Extract Multi Values to Points it was possible to obtain estimates of the landscape terrain aspects where the areas classified as Native Forest occurred in 2003, 2016 and, also, its deforestation and regrowth during the studied period.

\section{RESULTS}

\subsection{Image classification}

The spatial distribution of the land cover classes was defined through digital classification by maximum likelihood, producing subject images in five classes: Native Forest, Silviculture/Agriculture, Pasture, Exposed Soil and Water. The urban areas blend with the soil pixels due to the spectral similarity, therefore in this study those areas were inserted in the Exposed Soil class.

The validation of the image classification process was made through the confusion matrix from the years of 2003 and 2016. The kappa index values were 0.95 and 0.94 for the years of 2003 and 2016, respectively. According to the Landis and Koch (1977) scale, values above 0.81 are considered excellent. The overall accuracies were $96.8 \%$ for 2003 , and $95.5 \%$ for 2016 . Water class obtained lower values of user's accuracies in both 2003 and 2016 images classification, respectively $14.29 \%$ and $20.62 \%$ of pixels from other classes were erroneously classified as Water. Higher values of omission errors (producer's accuracy) were found for the classes Pasture (4.67\% in 2003), and Exposed Soil (9.00\% in 2016). Both imagens were correctly classified, even though the water had border effects since it was harder to identify water courses in the studied images, thus including mixed pixels in this class. For the 2003 and 2016 images classifications, respectively, $3.8 \%$ and $0.67 \%$ pixels from other classes were erroneously assigned to the Native forest class, and $1.67 \%$ and $2.21 \%$ of Native forest pixels were assigned to other classes.

\subsection{Forest dynamics in the Turvo Sujo watershed}

The SSF (Native forest class) in the Turvo Sujo watershed expanded 3,053 hectares between 2003 and 2016, going from 6,956 to 10,009 ha, therefore resulting in a decrease in the other land cover classes (Table 1).

Even with the increase of the area covered by SSF, it is noticeable that 1,088 hectares were deforested during the studied period in the studied watershed.

Revista Árvore. 2018;42(5):e420507 
From the original 2003 values of SSF, an area of 5,200 hectares remained until 2016.

Overall, the $42 \%$ increase in the areas covered by SSF occurred in the surrounding areas of the 2003 fragments. That emphasizes the natural regrowth and the enlargement of the original areas covered by SSF (Figure 2).

\subsubsection{Forest dynamic and its relationship with terrain aspects}

The terrain aspects of the Turvo Sujo River watershed are similarly arranged in the area, except the flat lands, that occupies only 14 hectares $(0.03 \%$ of the area).

In the years of 2003 and 2016 the SSF mostly occupied the Southern aspect, and, generally, presented the same distribution pattern over the slope faces of the terrain.

The deforestation pattern was also higher in the Southern aspect, between 2003 and 2016. Thus, the deforested area was larger in the slope faces turned to South, Southeast and Southwest. However, the natural regrowth did not follow the same pattern, expanding equally in all terrain aspects, except in the plain terrains (Figure 3).

\section{DISCUSSION}

The fragmentation of the native vegetation is a current characteristic in the Atlantic Forest domain. Pereira et al. (2017), as exposed in this paper, demonstrated that for the city of Vassouras, in Rio de Janeiro state,

Table 1 - Land cover and use in the Turvo Sujo River basin, in effective area and in percentage, in the years 2003 and 2016.

Tabela 1 - Uso e ocupação da cobertura da terra na bacia hidrográfica do Rio Turvo Sujo, em área efetiva e em porcentagem, nos anos de 2003 e 2016.

\begin{tabular}{lcccc}
\hline & \multicolumn{2}{c}{ Area (ha) } & \multicolumn{3}{c}{$\begin{array}{c}\text { Occupation } \\
\text { percentage in } \\
\text { the watershed (\%) }\end{array}$} \\
\hline Land use & 2003 & 2016 & 2003 & 2016 \\
\hline Native Forest & 6,956 & 10,009 & 17.2 & 24.8 \\
Silviculture/ & 8,914 & 6,315 & 22.1 & 15.6 \\
Agriculture & & & & \\
Pasture & 27,268 & 22,130 & 67.5 & 54.8 \\
Exposed Soil & 5,203 & 4,811 & 12.9 & 11.9 \\
Water & 1,798 & 2,877 & 4.5 & 7.1 \\
\hline
\end{tabular}
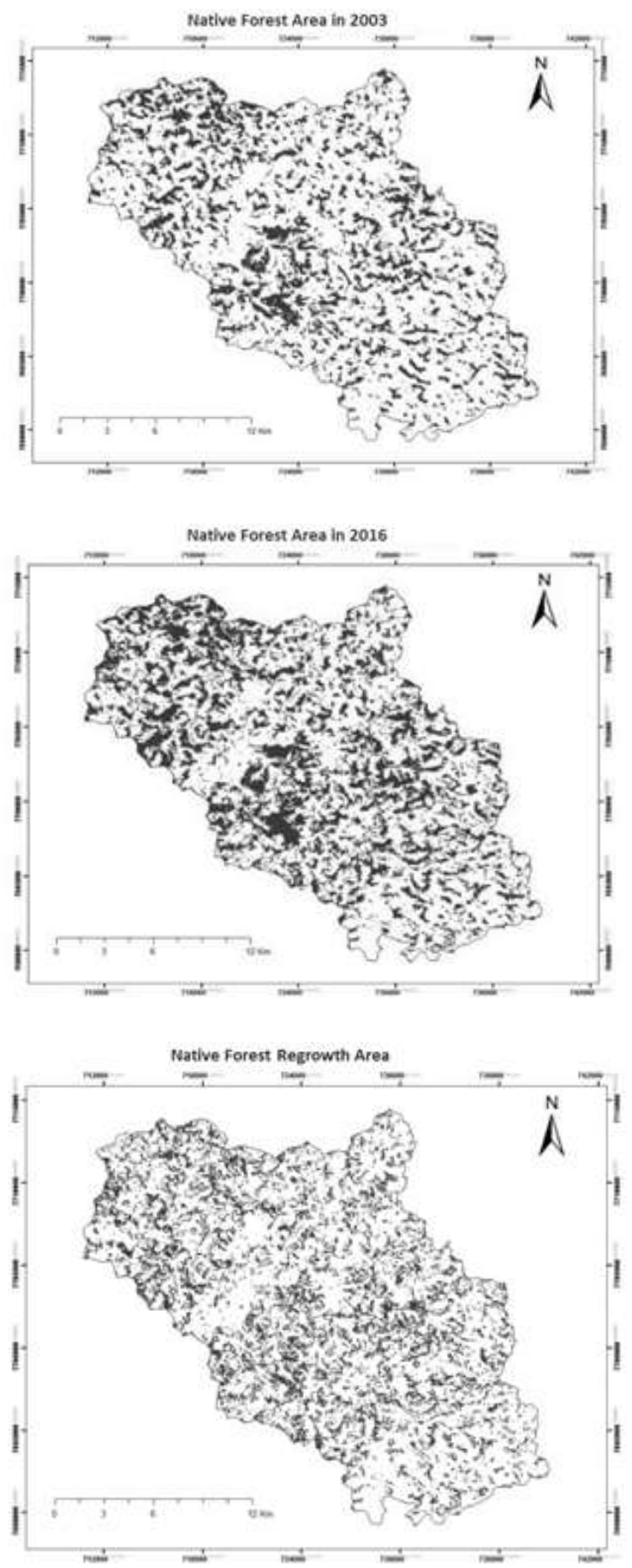

Figure 2 - Native forest cover in the years 2003 and 2016 and regrowth area, in the Turvo Sujo River basin, Minas Gerais.

Figura 2 - Cobertura de Floresta Nativa nos anos de 2003 e 2016 e área regenerada na bacia hidrográfica do Rio Turvo Sujo, Minas Gerais.

Revista Árvore. 2018;42(5):e420507 
Table 2 - Distribution of terrain aspects in the Turvo Sujo River basin area, Minas Gerais.

Tabela 2 - Distribuição das faces de exposição do terreno na área a bacia do Rio Turvo Sujo, Minas Gerais.

\begin{tabular}{lcc}
\multicolumn{3}{c}{ na área a bacia do Rio Turvo Sujo, Minas Gerais. } \\
\hline PLAIN & $\begin{array}{c}\text { Percentage } \\
(\%)\end{array}$ & $\begin{array}{c}\text { Effective area } \\
\text { (ha) }\end{array}$ \\
NORTH & 0.03 & 14 \\
NORTHEAST & 14.39 & 5,812 \\
EAST & 12.80 & 5,167 \\
SOUTHEAST & 11.56 & 4,667 \\
SOUTH & 11.75 & 4,745 \\
SOUTHWEST & 12.37 & 4,993 \\
WEST & 11.81 & 4,769 \\
NORTHWEST & 11.71 & 4,727 \\
\hline & 13.58 & 5,485 \\
\hline
\end{tabular}

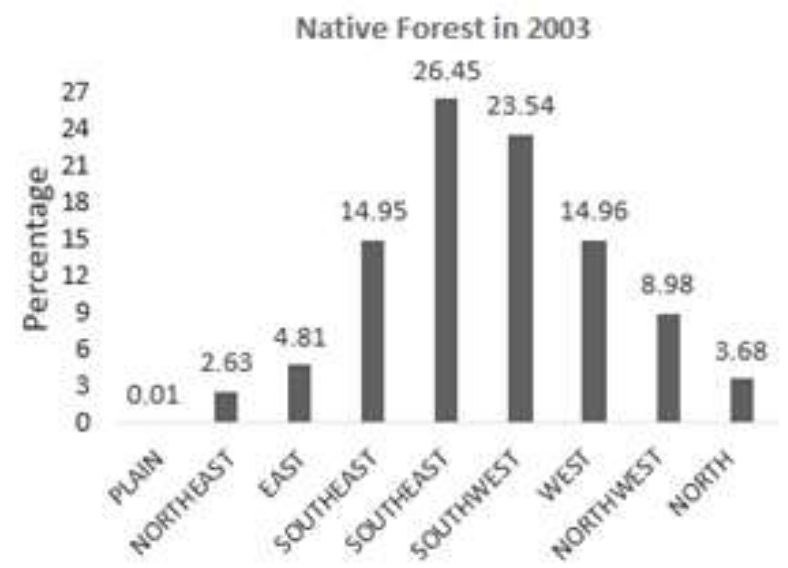

Deforestation between 2003 and 2016

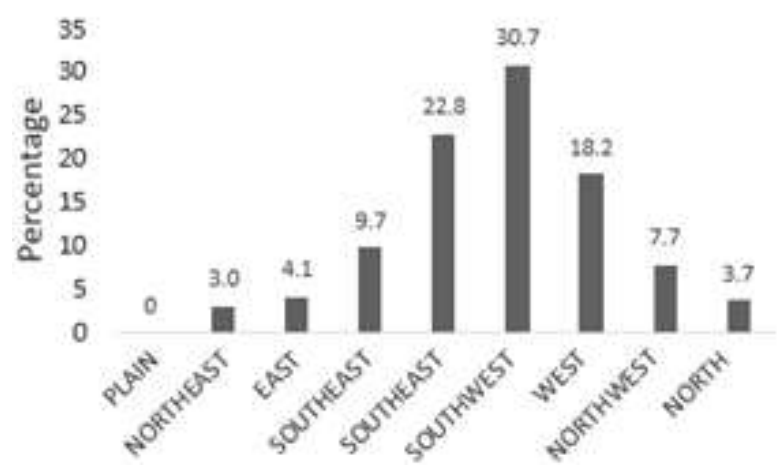

the native forest has $70 \%$ of its areas presented in small fragments under five hectares and only $2 \%$ in fragments larger than 50 hectares. In the region of Ouro Preto, in Minas Gerais state, Silva et al. (2015) verified that $55.34 \%$ of the area taken by Montainous Semideciduous Seasonal Forest had less than 3 hectares. In the Pequeno River watershed, in the state of Paraná, around $90 \%$ of the fragments of shrub and tree vegetation present areas smaller than 10 hectares (Rex et al., 2018).

The increase of the areas covered by SSF in the Turvo Sujo River watershed, in Minas Gerais state, southeastern Brazil, leaded to the decline of other land covers (such as Silviculture/Agriculture, Pasture, Exposed soil) between the years of 2003 and 2016. Nonetheless,

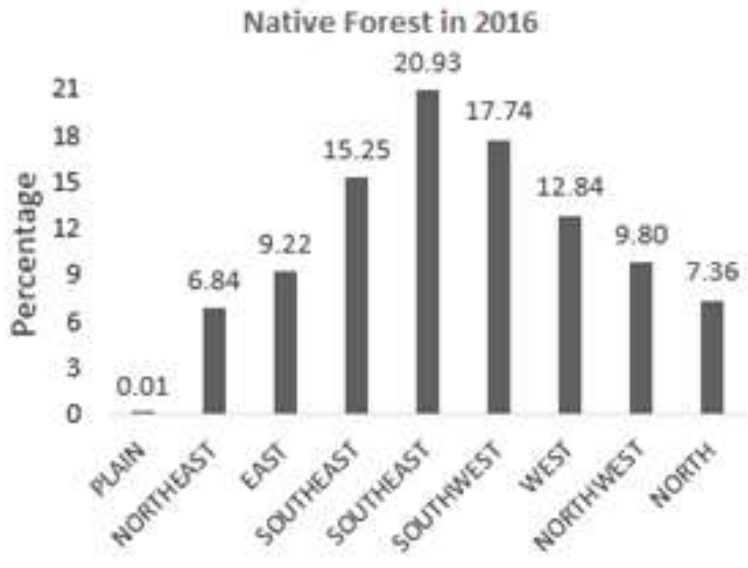

Regrowth between 2003 and 2016

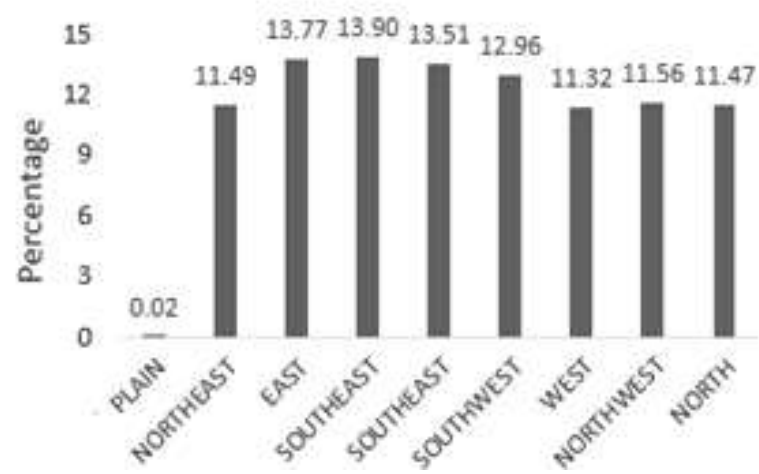

Figure 3 - Percentage of native forest in relation to exposure aspects in the years 2003 and 2016. And regrowth percentage of native forest deforested forest in the Turvo Sujo River basin, Minas Gerais.

Figura 3 - Porcentagem de floresta nativa com relação às faces de exposição, nos anos de 2003 e 2016. E porcentagem de desmatamento e regeneração na bacia hidrográfica do Rio Turvo Sujo, Minas Gerais.

Revista Árvore. 2018;42(5):e420507 
the class Water demonstrated an unexpected increase that might be explained by the highest user's errors for this class.

The increase of the SSF areas was clearly noticed in the edges of older fragments, which leads to the conclusion of natural regrowth. The enlargement of the fragments around their cores is essential for biodiversity. Thus the connectivity between fragments also increase, making easier for animals to move between fragments (Rezende et al., 2015). These new areas occupied by native forests in 2016, in 2003 were used with clonal tree plantation or agriculture (a total of 2,000 hectares), pasture (780 hectares), exposed soil (22 hectares), and 380 hectares classified as water in 2003.

The vegetation dynamic is highly impacted by the climate and topographic aspects of the areas. Ferreira et al. (2012) focus on the existence of microclimates in mountainous regions due to the relief characteristics, seasonality, earth rotation movement and terrain aspects, affecting, mostly, the micro-temperature. Rosa et al. (2017) divided the slopes of land exposure in four points (North, South, East, West) in a work carried out in Rio Grande do Sul state (RS). The largest areas covered by native forest were found in the Western and Southern aspects, respectively, and the Northern aspect the smallest, such as in this work, in which the largest forest extensions were found in the Southern and Southwestern aspects. In Vassouras, Rio de Janeiro state, the land uses did not variate according to the terrain aspects (Pereira et al., 2017), as well as in this research. However, Silveira and Silva (2010) noticed that the forest fragments evolved to advanced forest succession stages, especially in the Southern aspect of the Paquequer watershed (RJ).

The terrain aspect called "noruega" face, facing to the South, is usually moister and receives less solar irradiance, besides the occurrence of orographic lifts in the winter, enhancing the relative humidity in this face (Ferreira et al., 2012); those characteristics make them suitable for the native vegetation growing. That is visible in the images of 2003 and 2016, in which the slopes facing South have larger forest areas. The terrain aspect known as "soalheira", facing North, receive higher solar irradiance, influencing the soil temperature and consequently causing structural differences when compared to the other terrain aspects (Bierkeland, 1974).
Solar irradiation in the Eastern aspect of the terrain is stronger in the beginning of the day, while in the evening this aspect presents a cooling process and slightly shading (Ferreira et al., 2012). The same author states that the Western aspect begin their preheating process along with the sunrise and receive direct irradiation after $12 \mathrm{pm}$, which contributes to their average temperature being higher than in the slopes with Eastern aspects.

Natural regrowth itself did not present noticeable differences in relation to the terrain aspects, with exception to the plain terrains. The slopes with Northern aspect also went through a native forest recover, which can be explained by the possible abandonment of the land in the municipalities that host the basin (Cabral, 2016). Areas that used to be covered with coffee plantations now face abandonment due to the socioeconomic changes that the region has been undergoing (Rezende et al., 2015). In the municipalities of Frederico Westphalen and Três Passos, RS, the mapping of forest coverage presented an increase of $50,4 \%$, in area, between 1985 and 2014 , possibly caused by the abandonment of agricultural activities; all the slope aspects of the terrain had an expansion of forest coverage (Rosa et al., 2017). According to these authors, this leaded to the decrease of the rural population predominance resulting in a higher predisposition of the land to native forest recovering. That do not occur near urban areas because the intensive land use in these places (Rezende et al, 2015).

\section{CONCLUSION}

The Turvo Sujo River watershed, in southeastern Minas Gerais, Brazil, presented an area covered by Seasonal Semideciduous Forest (SSF) of 5,200 ha in 2016, and since 2003 it had a deforestation of 1,088 ha and a SSF regrowth of 3,053ha. The forest regrowth (42\%) occurred mostly in the edges of the forest fragments of 2003, revealing that the reestablishment of the SSF in the Turvo Sujo watershed has been occurring naturally. The coverage of SSF in plain areas is scarce due to the presence of only 14 hectares $(0.03 \%)$ of this type of terrain aspect in the studied region. The native forest covered larger areas in the slopes with Southern, Southeastern, Southwestern and Western aspects in both years, 2003 and 2016. The same pattern is observed for the deforestation, while there were no major differences in the forest regrowth in relation to the terrain aspects. This fact is relevant and positive, considering the importance of the native forest in the conservation of all slope aspects, 
in order to maintain the availability and quality of the hydric resources in the studied watershed. This basin has been strategic to supply water to the population of the municipalities that compound it; they have been suffering with the extensive and recurrent dry periods.

\section{REFERENCES}

Agência Nacional de Águas - ANA. Encarte especial sobre a crise hídrica. Brasília, DF: 2015. 30p. [acessado em: 18 abr. 2018]. Disponível em: http://www.snirh.gov.br/portal/snirh/centrais-deconteudos/conjuntura-dos-recursos-hidricos/ crisehidrica2014.pdf.

Bader MY, Geloof I, Rietkerk M. High solar radiation hinders tree regeneration above the alpine tree line in northern Ecuador. Plant Ecology. 2007;191(1):33-45.

Basnet K. Effect of topography on the pattern of trees in tabonuco (Dacryodes excels) dominated rain forest of Puerto Rico. Biotropica. 1992;24(1, p):31-42.

Bierkeland PW. Topography-soil relationships. Soil and Geormophology. New York: Oxford University Press; 1974. 372p.

Brasil. Ministerio do Meio Ambiente. Mata Atlântica. 2017. Disponível em: http:// www.mma.gov.br/biomas/mata-atlântica. [acessado em: 20 set. 2017]

Cabral IFQ. Análise de dados censitários e de cobertura florestal nativa em Viçosa - Minas Gerais e municípios limítrofes $(2000$ - 2010) [TCC] Viçosa, MG: Universidade Federal de Viçosa; 2016.

Caram RO. Reconstrução de séries e análise geoestatística da precipitação no estado de Minas Gerais [tese]. 2007. Viçosa, MG: Universidade Federal de Viçosa; 2007.

Carvalho PRS, Guimarães RF, Carvalho Júnior OA. Análise comparativa de métodos para delimitação automática das sub-Bacias do alto curso do Rio Preto. Espaço \& Geografia, 2010;13(2): 227-307.

Ceccon E, Huante P, Rincón E. Abiotic factors influencing tropical dry forests regeneration. Brazilian Archives of Biology and Technology. 2006;49(2):305-12.

Revista Árvore. 2018;42(5):e420507
Chazdon RL. Tropical forest recovery: legacies of human impact and natural disturbances. Perspectives in Plant Ecology, Evolution and Systematics. 2003;6(1-2):51-71.

Coelho CAS, Oliveira CP, Ambrizzi T, Reboita MS, Carpenedo CB, Campos JLPS. The 2014 southeast Brazil austral summer drought: regional scale mechanisms and teleconnections. Climate Dynamics. 2015;46(11-12):3737-52.

Cristofoletti A. Geomorfologia fluvial - V. 1 - O canal fluvial. São Paulo: Edgar Blücher; 1981.

Diniz FA, Ramos AM, Rebello ERG. Normais climatológicas do Brasil 1981-2010. Pesquisa agropecuária brasileira. 2018;53(2):131-43.

Ferreira E, Dantas AAA, Morais AR. Exatidão na classificação de fragmentos de matas em imagem do satélite CBERS-CCD, no Município de Lavras, MG. In: Anais do $13^{\circ}$ Simpósio Brasileiro de Sensoriamento Remoto. Florianópolis: 2007. São José dos Campos: INPE; 2007. p.887-894

Ferreira WP, Ribeiro MF, Fernandes Filho EI, Souza CF, Castro CCR. As características térmicas das faces Noruega e soalheira como fatores determinantes do clima para a cafeicultura de montanha. Brasília, DF: Embrapa Café; 2012. 34p.

Fundação SOS Mata Atlântica. A mata atlântica. 2017a. [acessado em:17 nov. 2017]. Disponível em:: https://www.sosma.org.br/nossacausa/a-mata-atlantica/.

Fundação SOS Mata Atlântica. Dados mais recentes. 2017b. [acessado em: 19 abr. 2018] Disponível em: https://www.sosma.org.br/projeto/ atlas-da-mata-atlantica/dados-mais-recentes/.

Instituto Brasileiro de Geografia e Estatística - IBGE. Manual técnico da vegetação brasileira. Rio de Janeiro: IBGE; 2012. (Série Manuais Técnicos em Geociências).

Instituto Nacional de Meteorologia - INMET. Precipitação total anual. Brasilia, DF. [acessado em: 18 abr. 2018]. Disponível em: http:// www.inmet.gov.br/portal/index.php?r=clima/ page $\&$ page $=$ desvioChuvaAnual.

Kayiranga A, Kurban A, Ndayisaba F, Nahayo L, Karamage F, Ablekim A, et al. Monitoring forest 
cover change and fragmentation using remote sensing and landscape metrics in Nyungwe-Kibira Park. Journal of Geoscience and Environment Protection. 2016;4(13):13-33.

Landis JR, Koch GG. The measurement of observer agreement for categorical data. Biometrics. 1977;33(1):159-74.

Oliveira RR, Zaú AS, Lima DF, Silva MBR, Vianna MC, Sodré DO, Sampaio PD. Significado ecológico da orientação de encostas no maciço da Tijuca, Rio de Janeiro. Oecologia Brasiliensis. 1995;1(1):523-41.

Pereira MPS, Francelino MR, Queiroz JMA. Cobertura florestal em paisagens do Médio Vale do Rio Paraíba do Sul. Floresta e Ambiente. 2017;24:e00134115.

Rex FE, Corte APD, Kazama VS, Sanquetta CR. Análise métrica da cobertura florestal da bacia hidrográfica do Rio Pequeno-PR. BIOFIX Scientific Journal. 2018;1(1):184-92.

Rezende CL, Uezu A, Scarano FR, Araujo DSD. Atlantic Forest spontaneous regeneration at landscape scale. Biodiversity and Conservation. 2015;24(9):2255-72.

Ribeiro MC, Metzger JP, Martensen AC, Ponzoni FJ, Hirota MM. The Brazilian Atlantic Forest: How much is left, and how is the remaining forest distributed? Implications for conservation. Biological Conservation. 2009; 142(6):1141-53.

Rosa PA, Breunig FM, Almeida CM, Balbino R. Avaliação das relações entre os parâmetros da modelagem geomorfológica e a cobertura florestal no noroeste do Rio Grande do Sul. Geo UERJ. 2017;31:371-88.

Santos GL, Pereira MG, Delgado RC, Moraes LFD. Padrões da regeneração natural na Região de Mar de Morros, Pinheiral-RJ. Floresta Ambiente, 2017;24:e20150081.

Silva AM, Herpin U, Martinelli LA. Morphometric characteristics of seven meso-scale river basins in state of São Paulo (southeastern Brazil). Revista Caminhos da Geografia. 2006;3(17):20-30.

Silva RA, Pereira JÁ, Barros DA, Borges LAC, Teixeira MD, Acerbi-Jr FW. Avaliação da cobertura florestal na paisagem de Mata Atlântica no ano de 2010, na região de Ouro Preto - MG. Cerne. 2015;21(2):301-9.

Silveira CS, Silva VV. Dinâmica de regeneração, degeneração e desmatamento da vegetação provocadas por fatores climáticos e geomorfológicos: uma análise geoecológica através de SIG. Revista Árvore. 2010;34(6):1025-34.

Shiba HM, Santos RL, Quintanilha JÁ, Kim HY. Classificação de imagens de sensoriamento remoto pela aprendizagem por árvore de decisão: uma avaliação de desempenho. In: Anais do $12^{\circ}$ Simpósio Brasileiro de Sensoriamento Remoto SBSR. Goiânia: 2005. São José dos Campos: INPE; 2005. p.891-8.

United States Geological Survey - USGS, Global Visualization Viewer (Glovis). [acessado em: 15 out. 2017] Disponível em: <http://glovis.usgs.gov/> . 